\title{
Baroko z hlediska rostlinné sociologie
}

Není jistě nikterak objevnou skutečností, že různí vědci vidí optikou svých věd svět různě - sociolog jinak než elektrotechnik a oba zas jinak než třebas hydrogeolog. Dědictvím z dob, kdy se vědní obory ustavovaly, je představa, že každá věda má výlučný př́istup ke svému objektu bádání, tedy že právu nejlépe rozumí právník, lidskému tělu lékař a Japonsku japanolog. Zpochybňovat toto rozdělení se nemusí vyplácet - přece jen ani nejlepší dentista nám neopraví počítač a ochořelého psa zrrídka uzdraví filolog. Přesto bývá užitečné, když se různé obory podívají na totéž - tedy totéž v užším smyslu, než že společenské vědy studují tutéž společnost a vědy přírodní tutéž přírodu.

Jednou z věd, které se občas jiných oborů neštítí, je historie, přičemž samozřejmě nejde jen o oblíbené pomocné vědy historické. Moderní historiografie se ve dvacátém století zajímala o antropologii, sociologii, ale i o fyzickou geografii. Díky francouzské škole Annales (u nás ještě dříve zásluhou Pekařovy Knihy o Kosti) tak vzniklo mnoho popisů každodenního života v různých dobách. Co se ale stane, když se na středověk nebo na období baroka podívá biolog, prezentující se jako rostlinný sociolog?

České baroko je vynikajícím příkladem uplatnění dvou hledisek, z nichž (jistěže notně zjednodušujícím způsobem) získáme dva zcela odlišné obrazy světa. Z hlediska dějin umění uvidíme a uslyšíme krásná díla a vynikající umělce - Brandla, Brauna, Michnu z Otradovic, nic nevadí, že pojmenování baroko, ona gymnaziálně proslulá „perla nepravidelného tvaru“, vzniklo jako posměšek. Z hlediska druhého, historického, uvidíme věci méně příjemné - války, pálení knih nebo mor. Biolog Jiří Sádlo tuto dvojakost charakterizuje vtipným zvoláním: „Není ten morový sloup rozkošný? Inu, baroko - tady ale musely být mory!“

K baroku samozřejmě patří obojí - a ještě mnoho dalšího (nelze nepřipomenout proslulou knihu Zdeňka Kalisty Tvář baroka). Věcně obohacující pohled nabídl v jedné z kapitol pozoruhodné knihy Krajina a revoluce právě „rostlinný sociolog“ Jiří Sádlo s kolektivem, složeným z archeologa, archeoložky, geologa a kulturologa. Sádlo ke standardnímu chápání, kdy barokem rozumíme zejména barokní památky nebo Jiráskovo Temno, říká, že „jde spíš o chybění určitých myšlenek než o chyby v myšlenkách“.

Jiří Sádlo se zajímá o celou českou barokní krajinu, přičemž krajinou nejsou myšleny jen kopce a pole kdesi v pozadí, ale vše, co barokní člověk okolo sebe viděl a v čem žil. Krajina je v tomto pojetí skrznaskrz kulturní, protože neoddělitelná od člověka a jeho činnosti. A náhle uvidíme, že mezi první čtvrtinou 17. a koncem 18. století se u nás formovala specifická kulturní krajina - krajina barokní. Doba pobělohorská umožnila nové šlechtě nový, silnější vliv na krajinu, přesně v duchu novověké racionality. Rozšiřují se pole, zefektivňuje se zemědělství, hnojí se, louky se nyní kosí pravidelně, vysoušejí se rybníky, masově se šiŕí nové druhy rostlin, zejména zámořských (kukuřice, rajčata, brambory), s módou přicházejí nové květiny (například tulipán), chovají se nová domácí zvírata (králík, krůta), kvůli začínajícím formám průmyslu se mění toky potoků a v důsledku těžby se krajina odlesňuje. Na podobu krajiny mělo významný vliv také budování drobnějších i větších staveb (kostely, mlýny, kapličky, boží muka) a nové sítě cest. V baroku se vliv člověka poprvé obrátil na krajinu jako celek - jsouc již zcela kolonizována, dostala se ve všech svých složkách do lidských rukou. „Až dosud se v krajině 
hledala místa vhodná pro daný účel. Ted’ se situace obrací - hledá se optimální účel pro dané místo. “ Člověk začal chápat krajinu jako materiál, objevila se touha ji spoutat a nastolit $\mathrm{v}$ ní řád.

Je pozoruhodné, jak pohled na historickou epochu jako na kulturní krajinu v sobě dokáže integrovat hledisko nejen kunsthistorické (architekturu nebo sochy od krajiny odmyslit nelze) a sociálně-historické, ale třeba i botanické. Jiří Sádlo má zjevně dojem, že činí cosi, co by se ve vědě činit jaksi nemělo, i proto se nebojí do knihy vnést ducha nesmírně poetického (Sádlo je také autorem poetického deníku Prázdná země). Tento duch však místy působí přespř́liliš „,revolučně“ (nejen kvưli názvu knihy) - možná trochu zbytečně. Vždyt do vědy by jak mezioborová komunikace, tak poezie patřit měly. Že se to neděje př́liš, je už věc jiná.

Krajina a revoluce je nepochybně také příspěvkem do diskuze o ochraně krajiny. Celou knihou se line zásadní poselství, že krajina zkrátka není oddělitelná od člověka, at̉ už s ní dělá cokoliv. Ostatně i v části o českém baroku Sádlo připomíná, že opravdu rekonstruovat barokní krajinu nelze, nebot již zkrátka v baroku nežijeme. Museli bychom dát pryč asfalt i elektřinu. „A pokud se zlato křížů neodrazí v př́ijičných vředech na sepjatých rukou v procesí vlekoucích se paralytiků, nebude to barokní krajina, ale hra na ni. Arci je taková podmínka př́lišná. Ale pak je třeba vědět, že to je hra a že k rekonstrukci barokní krajiny se sotva přiblížíme tím, že se budeme hrdlit o každý prejz na střeše."

Miroslav Pauliček 